\title{
Konsistensi Partai Keadilan Sejahtera di Luar Pemerintahan Joko Widodo pada Periode 2014-2019 dan 2019-2024
}

\author{
Sarah Soraya* \\ UIN Syarif Hidayatullah Jakarta \\ *Email: sarah.soraya16@gmail.com
}

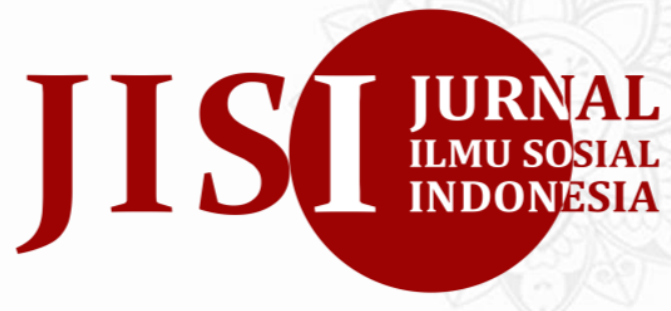

p-ISSN: 2808-9529 (Printed)

e-ISSN: 2808-8816 (Online)

Jurnal Ilmu Sosial Indonesia (JISI)

http://journal.uinjkt.ac.id/index.php/jisi

VOL. 2, NO. 2 (2021)

Page: 97 - 105

Recommended Citation:

Soraya, S. (2021). Konsistensi Partai Keadilan Sejahtera di Luar Pemerintahan Joko Widodo pada Periode 2014-2019 dan 20192024. Jurnal Ilmu Sosial Indonesia (JISI), 2(2), 97-105.

doi:https://doi.org/10.15408/jisi.v2i2.24955

Available at:

http://journal.uinjkt.ac.id/index.php/jisi/arti cle/view/24955

Article History:

Received 16 October 2021

Accepted 11 November 2021

Available online 28 December 2021

* Corresponding Author

\begin{abstract}
In 2019 Partai Keadilan Sejahtera (PKS) chose to be in another carriage of opposition, although other major parties tried to make friends with the government. Referring to the vote in the 2014-2019 elections, the number of PKS voters increased sharply by $36 \%$ to a difference of 3,013,459 votes, from 2019 to 2014. Therefore, this article will examine what factors made the Prosperous Justice Party choose to remain in opposition during the two periods of Joko Widodo's leadership as well as the impacts obtained both internally and governmently. This research uses qualitative method. The results showed that when compared to most other parties that voted to join the coalition, they chose to be consistent. This was done to attract new voters. On the other hand, they are is trying to defend its base of voters. The opposition is doing it in the legislative sector while still providing constructive inputs. The impact of the decision is to get a positive response with the increase in votes and flexibility in expressing opinions in parliament.
\end{abstract}

Keywords: Opposition, PKS, political parties, base voters, vote increase.

Abstrak. Pada tahun 2019 PKS memilih untuk berada di gerbong lain yaitu oposisi, meskipun partai besar yang lain beramai-ramai berusaha untuk berkawan dengan pemerintah. Mengacu pada perolehan suara pada pemilu 2014-2019, jumlah pemilih PKS mengalami kenaikan yang cukup tajam sebanyak 36\%. Sehubungan dengan itu artikel ini akan mengkaji faktor yang membuat PKS memilih beroposisi selama dua periode Joko Widodo serta dampak yang didapatkan baik internal maupun pemerintah. Penelitian ini menggunakan metode kualitatif. Hasil penelitian menunjukkan bahwa jika dibandingkan dengan kebanyakan partai lain yang memilih untuk bergabung dengan koalisi, PKS memilih untuk konsisten. Hal tersebut dilakukan untuk menarik minat pemilih baru, sekaligus berusaha mempertahankan para base voters. Oposisi dilakukan dalam sektor legislatif dengan tetap memberikan masukan-masukan konstruktif. Dampak dari keputusan beroposi yaitu mendapatkan respon positif dengan adanya kenaikan suara dan keleluasaan berpendapat dalam parlemen.

Kata Kunci: Oposisi, PKS, partai politik, base voters, kenaikan suara. 


\section{PENDAHULUAN}

Pembicaraan mengenai partai oposisi kembali ramai diperbincangkan kembali pasca pemilihan presiden 2019 atau periode Jokowi-Amin (2019-2024). Setelah PKS pmengemukakan keputusannya menjadi 'satu-satunya' partai oposisi yang dikampanyekan oleh Mardani Ali Sera dengan \#KamiOposisi beralasan bahwa oposisi lebih mulia dan sehat untuk demokrasi.

Pada periode sebelumnya PKS juga memilih untuk berada di luar Kabinet Indonesia Maju dalam pimpinan Jokowi-Jusuf Kalla. Jokowi-JK yang mendapat dukungan dari partai-partai besar sehingga menjadikan Koalisi Indonesia Maju (KIM) menjadi 'gemuk'. Dengan keberadaan Gerindra merapat ke pemerintahan. Gerindra, PKS, PAN dan Demokrat mengalami pecah kongsi dan hanya menyisakan PKS.

Hal tersebut juga dilihat dari komposisi MPR RI yang berisikan mayoritas dari kubu Jokowi, sedangkan DPR RI berisikan semua partai. MPR dipegang oleh Bambang Soesatyo, DPR dipegang oleh Puan Maharani, dan DPD dipegang oleh La Nyalla Mattalitti. Padahal sistem pemerintahan demokrasi tidak dapat berkembang secara baik apabila tanpa oposisi, karena oposisi dianggap sebagai manifestasi dari demokrasi.

Dengan adanya partisipasi serta koreksi terhadap pemerintahan merupakan suatu hal yang utama dibandingkan dengan pemilu itu sendiri. Keberadaan oposisi dapat dikatakan sebagai bagian yang penting dari perjalanan demokrasi. Pada dasarnya oposisi berfungsi sebagai kontrol atas sikap, pandangan atau kebijakan pemerintah, yaitu check and balance. (Noor 2016: 1).

Hal yang akan terjadi apabila suatu kekuatan atau kelompok tidak dianggap keberadaannya, maka akan muncul perasaan saling curiga serta melihatnya sebagai sebuah ancaman. Ketika hal itu benar-benar terjadi, maka selanjutnya terjadi konflik politik yang saling menjatuhkan, dari berbagai lapisan masyarakat sehingga mengakibatkan timbulnya keinginan untuk beroposisi menjatuhkan pemerintah. (Madjid 1998:7).

Selain itu pula, adanya kegiatan check and balance berguna untuk menghindari sebuah pemerintahan berubah menjadi oligarki atau otoriter. Sehingga dapat disimpulkan bahwa keberadaan oposisi secara tidak langsung sebagai upaya peningkatan kualitas demokrasi di Indonesia. Namun sayangnya, kelompok oposisi pada masa Joko Widodo-Ma'ruf Amin sempat diprediksi tidak akan ada oposisi. Padahal, sistem pemerintahan demokrasi tidak dapat berkembang secara baik apabila tanpa oposisi karena oposisi dianggap sebagai manifestasi dari demokrasi.
PKS digadang-gadang menjadi partai oposisi tunggal dalam masa pemerintahan Jokowi-Amin tahun 2019, hal tersebut dianggap sebagai bagian dari kebangkitan Islam politik dan PKS telah mengambil peluang tersebut. Menurut peneliti dari RSIS Singapura, Alexander Arifianto dalam tulisannya untuk Brookings Institute, ia menggambarkan kelompok-kelompok Islam garis keras akan selalu berada di posisi menentang Jokowi selama periode ke depan. Dari segi perolehan suara di tahun 2009, PKS mendapatkan 8.206.955 suara atau 7,88 persen. Pada saat itu, PKS mendukung pasangan Susilo Bambang YudhoyonoBoediono.

Selama pemerintahan Presiden Joko Widodo, PKS mengambil posisi sebagai oposisi pemerintah. Suara PKS meningkat tajam di Pileg 2019, yakni dengan mendapatkan 11.493 .663 suara atau setara dengan $8,21 \%$. Oleh sebab itu PKS merasa apabila partainya berada di luar pemerintahannya maka elektabilitasnya akan naik dan hal tersebut menguntungkan baginya. ("Mungkinkah Hanya PKS Yang Bertahan Jadi Oposisi?". 2019. Kompas. Diunduh 29 Juni 2019 (https://nasional.kompas.com).

\section{METODOLOGI}

Artikel ini merupakan hasil penelitian kualitatif yang menghasilkan data dalam bentuk deskriptif baik dengan lisan, pendapat, serta literatur-literatur yang digunakan untuk menjawab permasalahan. Penelitian ini mencoba mendeskripsikan tentang konsistensi partai oposisi dalam suatu pemerintahan khususnya mengenai keputusan PKS dalam menjadi partai oposisi di tahun 2014 dan 2019.

Jenis penelitian kualitatif dirasa tepat digunakan ketika penelitian tersebut bertujuan guna mencari informasi yang mendalam agar dapat menghasilkan informasi yang komprehensif terkait bahasan penelitian. Data Penelitian ini memanfaatkan teknik pengumpulan data melalui wawancara secara mendalam dengan Mardani Ali Sera (Ketua DPP Partai Keadilan Sosial), Pipin Sopian (Kepala Departemen Politik PKS), Firman Noor (Kepala Pusat Penelitian Politik LIPI), Adi Prayitno (Direktur Eksekutif Parameter Politik Indonesia), dan WB (Politikus). Wawancara dilakukan selama pandemi Covid-19 dan sedang diberlakukannya sistem PSBB. Selain wawancara penelitian ini berbasis pada library research baik dari jurnal, artikel online, buku, serta laporan kerja yang terkait dengan bahasan penelitian.

Dalam menganalisis konsistensi partai oposisi dalam suatu pemerintahan khususnya mengenai keputusan PKS dalam menjadi partai oposisi di tahun 2014 dan 2019, peneliti 
menggunakan teori partai politik (Maurice Duverger) dan macam-macam bentuk oposisi (Marcus Meitzner) untuk mengetahui posisi PKS berada dalam sistem presidensial. Adapun teori oposisi (Nurcholish Madjid) untuk mengetahui penyebab dan dampak memilih untuk tetap berada dalam gerbong oposisi.

\section{DINAMIKA OPOSISI PARTAI KEADILAN SEJAHTERA (PKS)}

Dalam kehidupan politik Indonesia, dengan ketiadaannya partai politik yang berjalan di jalur oposisi, maka akan mempersulit terjadinya pemerintahan yang seimbang dan efektif, dikarenakan suara yang seragam dengan penguasa. Dan hal ini tentu saja direspon oleh PKS yang menunjukkan prinsip untuk tetap teguh di jalur oposisi selama dua periode kepemimpinan Joko Widodo.

\section{A. Faktor Konsistensi PKS Pada Periode 2014- 2019 dan Periode 2019- 2024}

Konsistensi PKSI menjadi partai di luar pemerintahan selama kepemimpinan Presiden Joko Widodo tidak terlepas dari pilihan keputusan yang diambil oleh PKS berdasarkan berbagai pertimbangan baik secara internal maupun eksternal. Paling tidak ada tiga faktor yang menyebabkan PKS memutuskan untuk konsisten beroposisi selama dua periode masa kepemimpinan Joko Widodo, yaitu corak PKS sebagai match allprogrammatic, adanya peluang market politik, dan cairnya koalisi oposisi.

\section{Corak Partai Keadilan Sejahtera}

Mengacu pada tipologi partai yang dijelaskan oleh Maurice Duverger, dalam hal ini dapat terlihat bahwa PKS masuk ke dalam tipe partai match all-programmatic yaitu partai berusaha melakukan perluasan dukungan yang melintasi identifikasi partai yang selama ini sudah dibangun. PKS berusaha untuk memasukkan segala unsur yang diantaranya basis massa, bergantung pada eksistensi figur dan program yang memiliki sejarah kuat, serta memanfaatkan segala peluang untuk mendapatkan keuntungan baik segi citra maupun materi.

Hal ini dapat dilihat melalui banyaknya LSM kegiatan sosial yang berafiliasi dengan PKS. Dengan banyaknya kegiatan sosial yang rutin dilakukan setiap hari, bukan hanya lima tahun sekali, hal tersebut mencirikan kegigihan PKS dalam melebarkan cakupannya dan bukan hanya sebagai partai elektoral saja. Meskipun demikian, PKS juga tidak terlalu membuka lebar peluang pendaftaran untuk menjadi kader maupun kandidat, sehingga cenderung masih tertutup. Tidak sembarang orang dapat mendapatkan posisi, hingga kemudian dicalonkan oleh PKS pada level publik.

Sejauh ini apabila dilihat lagi dari sisi corak warna ideologi yang dianut oleh PKS sebagai partai Islam, dapat dibilang masih memegang teguh warna ideologinya, meskipun partai lain juga sebenarnya melakukan hal yang sama. Akan tetapi menurut PKS, mendukung serta mencari kandidat yang menurutnya terlihat lebih islami serta didukung oleh komuitas-komunitas Islam yang besar dan kuat itulah yang lebih utama.

Sehingga di periode pertama ini bagi Adi Prayitno dapat dilihat bahwa PKS cukup kritis, masif dan berani dalam mengkritik kebijakan yang dikeluarkan pemerintah. Serta mengampanyekan isu-isu yang sifatnya menargetkan secara langsung perihal corak keberagamaan Joko Widodo. Hal tersebut menguat apabila melihat corak ideologi politik yang PKS miliki sangat islami. Jika dibandingkan dengan partai lainnya seperti PKB, PAN, PPP, yang terlihat sangat islami seakan-akan hanya PKS. Dengan adanya hal tersebut menjelaskan alasan PKS memilih untuk oposisi terhadap pemerintahan Joko Widodo di periode pertama. Pada periode pertama ini figur Prabowo memiliki spotlight yang lebih besar ketimbang dengan partai oposisi lainnya yang merupakan anggota KMP seperti PKS. Meskipun PKS juga terbilang vokal dalam mengampanyekan \#2019GantiPresiden.

Kemudian untuk di periode kedua, apabila ditelusuri dari berbagai pemberitaan di media, isu yang diangkat dalam kampanye di tahun 2019 pada umumnya berkaitan dengan corak keagamaan Joko Widodo dan keberpihakan Joko Widodo terhadap asing. Berdasarkan hasil perolehan suara yang dikeluarkan oleh KPU di tahun 2009-2014, PKS bahkan mengalami penyusutan suara sebanyak $1,42 \%$ atau 118.965 suara. Dengan perolehan suara sebanyak 7,89 persen di tahun 2009 dan sebanyak 6,79\% di tahun 2014 .

Beberapa alasan penurunan suara yang terjadi ini sempat dituliskan dalam jurnal milik Suryani, diantaranya:

1. Adanya kegagalan figur kepemimpinan dalam tubuh PKS. Salah satunya ialah dampak dari kasus korupsi impor daging sapi di tahun 2013 yang menyeret mantan presiden PKS, Luthfi Hasan Ishaaq. Hal tersebut dimanfaatkan dengan mudah oleh pihak musuh untuk membangun opini di masyarakat.

2. Perpecahan isu dan penempatan posisi partai dengan identitas nasional. Pada waktu-waktu tertentu partai dapat merubah identitasnya dari konservatifnya menjadi identitas yang 
baru menyesuaikan dengan dinamika politik. Hal ini beresiko menimbulkan kekecewaan base voters PKS, dengan meyakinkan basis tradisional dengan pasar pemilih baru. Hal tersebut juga menyebabkan konflik internal yang melahirkan dua kubu antara Faksi Keadilan dan Faksi Sejahtera. Bahkan dalam Jurnal Politika, ditambahkan bahwa pada saat masa kepemimpinan PKS di tahun 2015-2020 pengelompokan dalam internal PKS berlanjut menjadi Osan (Orang Sana) dan Osin (Orang Sini). Orang sini adalah kubu PKS yang sedang berkuasa (loyalis partai), sedangkan orang sana ialah mereka yang tidak berkuasa lagi (loyalis Anis Matta). (Akmar, 2019:8-9).

3. Keberadaan partai alternatif. Hal ini merupakan tindakan lanjutan apabila konflik dalam internal tidak kunjung terselesaikan. Para base voters yang merasa kecewa dengan partai, akan berubah haluan menjadi medial voters atau pemilih yang melihat kandidat dari kemampuannya, bukan lagi melihat dari berasal dari partai mana. Dengan demikian tidak menutup kemungkinan beberapa partai lain memiliki peluang untuk mengambil medial voters tersebut, dengan memanfaatkan garis ideologis yang memang sesuai dengan kepercayaan. (Suryani 2017:201).

Selain ketiga alasan di atas, bibit oposisi terhadap Jokowi mulai berkembang menjadi besar, terlihat dari pengalaman pada masa Jabatan SBY di tahun 2009 meskipun PKS berada dalam gerbong koalisi, terlihat beberapa kali mengkritik kebijakan yang dikeluarkan oleh SBY misalnya soal kenaikan BBM serta hak angket Century. Dikarenakan kerap kali berani berpikir kritis itulah, maka PKS memilih untuk berada di gerbong oposisi.

Di tahun 2019 pun masih sama yaitu menjadi oposisi. Hal tersebut disebabkan oleh yang pertama, PKS kalah dalam pemilu sehingga menjadi oposisi. Berbeda dengan Golkar, PPP, PAN yang mendukung Prabowo di tahun 2014, pada akhirnya berpindah gerbong untuk berkoalisi dengan Jokowi. Sedangkan PKS memang konsisten dan sudah sejak awal pilihan apabila kalah dalam pemilu akan menjadi oposisi.

Kemudian apabila dilihat dari warna ideologi politiknya yaitu PKS merupakan salah satu partai politik yang masih berusaha untuk memegang teguh corak partai Islam. PKS selalu mencari dan mendukung kandidat yang menurut mereka terlihat lebih islami atau bahkan didukung oleh banyak komunitas islam yang relatif kuat dan lebih besar.

Kemudian faktor lain yaitu rasa kekecewaan yang dimiliki oleh PKS juga sudah tidak terbendung lagi. Seperti beberapa kursi yang seharusnya dimiliki oleh PKS akan tetapi diberikan kepada Gerindra. Hal tersebut dapat dilihat dari kursi wakil gubernur DKI yang harusnya milik Mardani Ali Sera akan tetapi diduduki oleh Sandiaga Uno, Pilgub Jabar tahun 2018 yang awalnya kader PKS Achmad Syaikhu-Deddy Mizwar akan tetapi berganti menjadi Sudrajat- Deddy Mizwar. Kemudian kursi calon wakil presiden, PKS ingin kadernya yang maju, akan tetapi yang diusung oleh koalisi ialah Prabowo Subianto-Sandiaga Uno yang notabene keduanya adalah kader Gerindra.

Sehingga di tahun periode pertama 20142019 dan periode kedua 2019-2024 oposisi terhadap kepemimpinan Jokowi, tidak ada perubahan yang terlalu signifikan. Cenderung terlihat masih memiliki semangat yang sama yaitu anti Jokowi dan ingin mengganti presiden. Karena memang yang menciptakan \#2019GantiPresiden ialah Mardani Ali Sera dan kawan-kawan PKS. Kemudian dalam perkembangannya kemudian terjadi snowball effect, gerakan \#2019GantiPresiden menjadi gerakan politik yang luar biasa dan terjadi di berbagai daerah. Bahkan sering kali terjadi pelarangan penggunaan tagar dan atribut seperti kaos-kaos yang bertuliskan \#2019GantiPresiden.

Dari sinilah dapat dilihat keseriusan PKS yang memang sejak awal berniat untuk mengganti rezim atau pemerintah dan tentu saja dengan caracara yang prosedural. Hanya saja terjadi modifikasi dari pola perlawanannya yang lebih agresif dibandingkan periode pertama di 2014. Karena memang di 2014 lebih cenderung berfokus kepada prabowo yang memiliki efek besar yang disebutkan oleh Leo Agustino sebagai "Prabowo Effect". (Agustino 2014:144).

Jika dibandingkan dengan PAN, Demokrat, atau partai pendukung prabowo lainnya, di tahun 2019 ini PKS tampak seperti partai yang paling semangat untuk mengampanyekan ganti presiden. Selain itu juga, tak lupa untuk mengampanyekan isu-isu yang memang bertujuan untuk menurunkan elektabilitas Joko Widodo, bahkan tak jarang pula banyak yang beranggapan bahwa isu yang beredar di masyarakat merupakan kampanye yang sifatnya negatif atau black campaign.

Bagi Firman Noor, hal tersebut dianggap sebagai suatu yang wajar mengingat memang seperti itulah tujuan dari masa kampanye yaitu mempromosikan diri sendiri dengan tujuan untuk membuat kandidat lain terlihat untuk tidak pantas dipilih. Tentu saja pengertian ini menggambarkan bahwa freedom of speech menjamin bahwa demokrasi masih berjalan di suatu negara. 
Membiarkan masyarakat untuk mengkritik dan kemudian menilai sendiri mana yang baik dan buruk, kemudian memutuskan untuk memilih kandidat mana yang pantas untuk dipilihnya. Adanya bantuan dari pers juga berpengaruh dalam menjamin kebebasan berpendapat tersebut. Melihat kasus yang terjadi semasa Orde Baru yaitu terjadi pelarangan atau pencabutan SIUP bagi kantorkantor media yang menyarankan tidak setujunya terhadap pemerintah, maka hal tersebut secara tidak langsung sudah menggugurkan prinsip dari freedom of speech dalam demokrasi.

Berbeda dengan PAN dan Demokrat yang sejatinya tidak menunjukkan sikap oposisinya secara terang-terangan kepada penguasa, dimana hal tersebut dapat terlihat memiliki catatan politik dua kaki pada Pilpres 2019 kemarin. Terlihat PAN dalam Pilpres 2019 mendukung Prabowo akan tetapi ikut dalam kabinet Jokowi dan mendapatkan kursi menteri Jokowi. Kemudian Demokrat sendiri terlihat memberikan kebebasan kepada sebagian kadernya untuk mendukung Joko Widodo-Ma'ruf Amin serta sebagian lainnya secara resmi mengusung Prabowo-Sandiaga Uno. Padahal perlu dilihat kembali bahwa dalam sistem presidensial, sikap partai menjadi penting. Hal tersebut dapat mempengaruhi pandangan masyarakat dalam memberikan dukungannya.

Adapun untuk mekanisme pengambilan keputusan beroposisi sendiri diputuskan melalui Majelis Syuro dengan melewati beberapa mekanisme pembahasan dan argumentasi disampaikan oleh DPTP (Dewan Pimpinan Tinggi Partai) terdiri dari Ketua Majelis Syuro, Wakil Ketua Majelis Syuro, Sekretaris Majelis Syuro, Presiden PKS, Sekretaris Jenderal, Bendahara, Ketua Majelis Pertimbangan Partai, Ketua Dewan Syariah Partai. Setelah diajukan proposal oposisinya kemudian tahap selanjutnya ialah Majelis Syuro mengadakan sidang dan membahas dari berbagai argumentasi kenapa PKS kembali Oposisi. Ini memperlihatkan bahwa Majelis Syuro bertindak sebagai lembaga tertinggi dan yang paling utama bagi PKS.

\section{Peluang Market Politik}

Sejauh ini PKS diketahui sebagai partai yang melakukan proses kaderisasi yang kuat dan ketat. Bestian Nainggolan pun menyebutkan bahwa hal tersebut sudah menjadi ciri khas tersendiri dan bahkan disebutkan sebagai satu-satunya partai kader yang mampu bertahan. (Nainggolan 2016:68).

Jika dilihat dari sikap-sikap yang ditunjukkan oleh PKS di tahun 2014 selain disebabkan memang tidak mendukung Joko Widodo, ialah PKS menganggap Joko Widodo sebagai orang yang kurang terlihat islami, atau misalnya saja dari segi faktor partai asal yaitu nasionalis sekuler.

Hal tersebut kemudian menjadi pertimbangan bagi PKS, yang memang pada dasarnya memiliki perbedaan yang sangat jauh dengan prinsip atau warna ideologi yang dianut oleh PKS. Sehingga sikap ini bukanlah terjadi secara mendadak setelah pengumuman KPU bahwa Prabowo kalah dalam pemilu. Melainkan memang sudah dari sejak awal sikap PKS yang dilontarkan oleh elit-elitnya secara tegas menginginkan menjadi oposisi. Keputusan untuk menjadi oposisi ini juga dianggap merupakan jalan terbaik untuk memperjuangkan dakwah politik PKS.

Selain itu pula PKS memiliki harga diri yang dijunjung tinggi, dan hal tersebut bagi Firman Noor akan mempengaruhi psikologi partai apabila merapat ke barisan koalisi maka statementstatement yang sudah dikeluarkan akan sia-sia saja sehingga dianggap kurang menguntungkan bagi partai. Atau dengan kata lain, di masa kampanye pemilu periode 2019-2024, hampir semua isu-isu yang dikeluarkan menghantam langsung ke Joko Widodo, contohnya saja \#2019GantiPresiden atau isu pro-asing. Jika harus tebalik secara 180 derajat berubah menjadi selalu memuji kinerja Joko Widodo maka hal tersebut akan menjadi paradoks politik.

Adapun yang sedang dipraktikkan oleh PKS ini mengindikasi-kan bahwa semakin dia menjaga jarak dengan kekuasaan, semakin kritis pula terhadap pemerintahan. Kemudian pada saat yang bersamaan kelompok-kelompok yang memang dari awal ingin ganti presiden atau rezim, maupun yang memang masih abu-abu, yang dahulunya berasal dari pendukung Prabowo dan Gerindra, harapan-nya ialah memberikan suaranya ke PKS. Sehingga inilah market politik yang sebenarnya ingin disasar oleh PKS.

PKS memutuskan untuk menjadi partai tengah dan terbuka, atau dengan kata lain mempunyai target elektoral untuk menjadi partai yang besar, dengan cara menerap-kan ijtihad politik guna menarik perhatian pemilih baru (captive market) namun tak mengorbankan base voter. Dengan kata lain partai yang sifatnya pluralis dan terbuka seperti PAN dan PKB pun belum tentu mampu menarik perhatian pemilih non-muslim dan sekuler. Sehingga PKS pun harus berani bermain isu lain selain isu keagamaan guna menarik perhatian pemilih yang semakin moderat. (Muhtadi 2012:212-215).

Keberadaan partai oposisi di Indonesia dalam sistem presidensialisme terbagi menjadi dua yaitu antara legislatif serta eksekutif. Dalam konteks PKS jika merujuk pada dua pilihan tersebut, mereka menyatakan sikap untuk menjalankan oposisi di ranah parlemen dibandingkan harus berada di luar parlemen. Mengingat apa yang dilakukan oleh PKS bukan berfokus dalam sektor eksekutif melainkan fokus memperjuangkan aspirasi di sektor DPR atau legislatif. Sebagaimana yang telah dijelaskan oleh Dahl 
yaitu perdebatan dalam parlemen tidak hanya semata mempengaruhi partai politik lainnya, akan tetapi akan lebih jauh penting untuk mempengaruhi publik.

Peluang ini akan jauh sangat menguntungkan bagi PKS mengingatt banyaknya isu-isu dan rancangan undang-undang yang sedang disorot oleh publik seperti RUU Omnibuslaw. Selain itu pula PKS ini melihat dinamika pada masa pemerintahan Joko Widodo yang terkesan terbelah menjadi dua yaitu hitam putih, antara pendukung Jokowi dan bukan pendukung Jokowi.

Selama pemilu di tahun 2019 suasana politik terbelah menjadi dua kubu, masing-masing kubu memiliki panggilan khusus yaitu 'cebong' dan 'kampret'. Hal itu menunjukkan dengan jelas bahwa pilihan politik di masa itu antara setuju dan tidak setuju. Hal ini tentu saja menguntungkan bagi PKS. Karena apabila memutuskan untuk berada di tengah (abu-abu) dalam menentukan sikap politiknya itu, maka ada kemungkinan PKS akan kehilangan kepercayaan konstituennya serta disisi lain hal tersebut merupakan pilihan untuk mematikan eksistensi PKS yang dianggap tidak punya sikap.

Sehingga meskipun Prabowo kalah dalam pemilu, PKS tetap tidak bergeming dan tertarik untuk masuk ke dalam koalisi. Dari hal tersebut sudah menunjukkan bahwa memang sejak periode pertama masa pemerintahan Jokowi, pilihan politik PKS adalah oposisi. Serta berusaha untuk menjalankan visi misinya. Pilihan politik PKS untuk konsisten, istiqamah dalam menjadi oposisi itu adalah bagian dari strategi politik juga, selain untuk meyakinkan para loyalis dan pendukungnya.

Sehingga dapat disimpulkan bahwa PKS sebenarnya ingin menyasar kelompok-kelompok yang selama ini tidak setuju dengan gaya kepemimpinan Jokowi serta masyarakat yang masih abu- abu. Menyasar tingkat elaktibilitas yang lebih tinggi lagi, paling tidak 7\% hingga 10\%, sampai dua digit tingkat elaktibilitasnya.

Dengan cara menggalang serta mengkonsolidasi dukungan-dukungan yang berasal dari kelompok-kelompok kritis dan anti pemerintah. Pilihan politik PKS dalam banyak hal ini cukup menguntungkan. Karena masyarakat kita itu sekarang kalau tidak Jokowi ya anti Jokowi. Hal tersebut pun dibuktikan oleh PKS setelah Prabowo kalah di tahun 2014. Sehingga bisa disimpulkan secara sederhana bahwa sikap politik yang dianut oleh PKS ialah sikap hitam putih. Jika menang akan menjadi penguasa, jika kalah akan jadi oposisi.

\section{Cairnya Koalisi Oposisi di Indonesia}

Jika merunut ke belakang, pertama, pada 14 Juli 2014 partai-partai yang kalah dalam Pilpres membentuk koalisi partai oposisi yang dinamakan Koalisi Merah Putih (KMP) dengan beranggotakan
Gerindra, Golkar, PAN, dan PKS yang apabila ditotalkan jumlah kursinya mencapai 292 buah. Sedangkan partai pendukung Joko Widodo diberi nama Koalisi Indonesia Hebat $(\mathrm{KIH})$ dengan total perolehan kursi sebanyak yang berasal dari PDI Perjuangan, Nasdem, PKB, Hanura dan PKPI. Adanya pembentukan koalisi partai oposisi ini disebabkan karena tak ada satu pun partai yang memenuhi ambang batas suara sebagai syarat mutlak untuk mengajukan calon presiden dan wakil presiden. (Admojo 1972:302).

Sebagaimana yang termaktub dalam Pasal 9 Undang-Undang Nomor 42 Tahun 2008 tentang Pemilihan Umum Presiden dan Wakil Presiden yang berbunyi, "Pasangan Calon diusulkan oleh Partai Politik atau Gabungan Parlai Politik peserta pemilu yang memenuhi persyaratan perolehan kursi paling sedikit 20\% jumlah kursi DPR atau memperoleh $25 \%$ dari suara sah nasional dalam Pemilu anggota DPR, sebelum pelaksanaan Pemilu Presiden dan Wakil Presiden."

Kemudian yang kedua ialah KMP pada awalnya dibentuk sebagai tandingan dari pendukung Jokowi-JK, yang disebabkan karena tidak terima dengan kemenangan Jokowi-JK dalam Pilpres serta persentase elektabilitas yang tinggi menurut hasil Pol-Tracking Institute. (Admojo 1972:288).

Dari hasil survei seperti yang dikutip oleh Tuswoyo Admojo tersebut, menunjukkan adanya penurunan kepercayaan publik terhadap masa pemerintahan SBY. Hal tersebut mengakibatkan masyarakat lebih percaya terhadap pihak oposisi, pihak oposisi pada saat 2014 itu ialah PDI Perjuangan, sehingga terjadi polarisasi di tubuh DPR. Lalu di kemudian hari partai-partai yang awalnya berada dalam gerbong KMP dengan mudahnya menjadi pendukung.

Sehingga dapat disimpulkan bahwa fungsi oposisi dalam tubuh KMP tidak berjalan dengan efektif. Perilaku seperti inilah yang membuat oposisi di Indonesia menjadi tidak kuat dan cenderung lemah. Elit yang selalu ingin dekat dengan kekuasaan, dan pemahaman mengenai oposisi dari para elit juga yang masih beranggapan bahwa oposisi identik dengan tidak ada kawan dan tidak mendapatkan dukungan. (Noor 2016:9).

Dalam praktiknya untuk memilih koalisi dan oposisi dalam banyak hal juga banyak ditentukan oleh berbagai isu-isu politik tertentu yang ada di badan legislatif. Salah satu contohnya seperti dalam kasus misalnya Kartu Pra Kerja terdapat perbedaan pendapat beda yang terjadi di partai-partai pendukung Jokowi. PDI Perjuangan dan PKB mengkritisi kebijakan tersebut yang dianggap memanjakan start up ataupun perusahaan perusahaan penyedia jasa online yang ditunjuk tanpa tender. Oposisi memang cenderung belum 
mendapat-kan dukungan penuh dan sering kali seperti ditinggalkan sendirian. Akan tetapi dalam banyak hal juga dirangkul untuk kebutuhan isu-isu politik lain yang berkembang di DPR dan pemerintah ini guna kepentingan komsumsi partai.

Kondisi ini artinya sudah sejak dulu oposisi itu menjadi pendirian yang ditinggalkan tergantung isu yang berkembang, tergantung isu yang digandrungi atau tidak oleh partai partai politik. Ketika sebuah partai memilih jalan oposisi, maka harus dapat menyesuaikan diri apabila ada risiko untuk berjalan di tempat yang sunyi, tidak ada akses politik, tidak ada akses ekonomi yang bisa dikapitalisasi sebagai resource politik jangka panjang. Akan tetapi, yang memilih untuk menjadi oposisi tidak selalu hanya dari kalangan partai politik saja, melainkan ada pula dari kalangan organisasi masyarakat, para aktivis, cendekiawan, dan bahkan media massa.

\section{B. Implikasi Kebijakan DPP Partai Keadilan Sejahtera (PKS)}

Jika dibandingkan dengan partai lain, PKS dapat dikatakan lebih mampu memanfaatkan momentum di periode kedua. Hal ini terlihat pada periode sebelumnya di tahun 2014, perolehan suara PKS di tahun 2019 melonjak tajam sebanyak 3.013.459 suara atau setara dengan $36 \%$, dari 8.480.204 menjadi 11.493.663.

Pada awalnya kemampuan untuk menarik minat masyarakat untuk memilih PKS sempat diragukan oleh mantan kadernya sendiri yaitu Fahri Hamzah, yang mengatakan "Kalau yang dibangun kultur pimpinan PKS sekarang nih susah. Ngurus DKI saja enggak beres-beres, banyak masalah, yang enggak sanggup kerjakan akhirnya mecat-mecatin orang. Nih, sekarang bagaimana saya mau prediksi PKS lolos threshold?" (Kompas.com, 2019) Dalam konteks kenaikan suara yang signifikan inilah sebagai bukti dari dampak positif yang mereka lakukan di periode sebelumnya. Sehingga PKS tidak menyia-nyiakan kesempatan emas untuk memanfaatkan momentum ini dengan selalu mengeluar-kan isu-isu yang tidak hanya berhubungan dengan keagamaan akan tetapi mencoba untuk merambah isu lainnya saat masa kampanye di tahun 2019 kemarin.

Dengan pencapaian elektabilitas tetap di atas $7 \%$ inilah, secara faktual merupakan jawaban atas keraguan Fahri Hamzah yang secara terang-terangan menganggap pesimis PKS. Dengan begitu diharapkan PKS mampu mendorong semangat para kader dan aktivis-aktivis untuk lebih gencar dalam mempromosikan kegiatan-kegiatan partai.

Dalam hubungan sebab akibat dari keputusan untuk konsisten menjadi oposisi, tampaknya tidak ada masalah yang terlalu signifikan bagi internal PKS maupun pemerintah sendiri. Sebagaimana yang telah dijelaskan oleh Nurcholis Madjid dalam bukunya yang berjudul "Dialog Keterbukaan", partai oposisi baginya ialah partai yang sudah kalah atau tidak lolos dalam pemilu, sehingga secara otomatis akan menjadi partai oposisi. Akan tetapi masih banyak salah persepsi di kalangan masyarakat dan pemerintah.

Istilah oposisi secara umum diartikan sebagai suatu kelompok yang memiliki kekuatan untuk mengoreksi suatu rezim apabila dianggap keliru serta berada di luar rezim tersebut. Tak jarang pula ada yang mengartikannya sebagai pemberontak. Meskipun pada kenyataannya oposisi sendiri sifatnya tidak mutlak di sistem politik Indonesia. Biasanya pandangan tersebut berasal dari kaum elit pemerintah yang sudah lebih dahulu menganggap bahwa ide oposisi ialah negatif.

Nurcholis Madjid mengatakan bahwa kelompok oposisi atau partai oposisi juga dapat diajak kompromi untuk berjalan beriringan dengan pemerintah, bertugas sebagai pengingat atau penasihat pemerintah yang sedang berkuasa apabila terdapat penyimpangan dalam menjalankan tugasnya. Karena kekalahan dalam pemilu bukan berarti tidak bisa berkontribusi lagi, melainkan diharapkan untuk tetap dapat memberikan kontribusi demi membangun demokrasi yang semakin baik. Bersedia untuk mengoreksi dan dikoreksi merupakan kunci kesuksesan dari demokrasi itu sendiri. (Madjid, 1998:7).

Sebenarnya PKS apabila berpisah dari kekuasaan tidak akan rugi apa-apa. Bahkan dapat dibilang di tahun 2014 PKS terlalu banyak berkorban untuk sekutunya yaitu Gerindra. Hal tersebut tampak dari beberapa kursi yang seharusnya merupakan kuota untuk PKS akan tetapi diberikan kepada Gerindra. Dengan berpisahnya PKS dari Gerindra, memang sekilas tampak seakanakan tidak memiliki partner dalam menentukan dan merumuskan kebijakan politik apa pun. Sehingga terlihat seperti dikucilkan secara politik.

Sebagai fraksi yang mandiri di parlemen, PKS tentunya akan lebih leluasa untuk melakukan kontra opini terhadap isu-isu yang sedang di bahas dalam parlemen. Ingin melakukan walkout akan menjadi terasa lebih ringan dikarenakan bukan berasal dari gerbong pemerintah. Hal tersebut menjadikan PKS semakin siap untuk menghadapi partai-partai yang berasal dari gerbong kekuasaan. (Madjid,1998:7).

Meskipun demikian, hal yang perlu diingat bahwa sekalipun PKS dianggap berpengaruh ataupun tidak oleh Joko Widodo dan berjalan sendirian, PKS memiliki mesin partai politik yang terkenal solid dan kuat, sehingga memungkinkan PKS untuk dapat bertahan di tengah keterbatasan dalam gerbong kekuasaan. Seperti yang sudah 
dijelaskan sebelumnya bahwa PKS memiliki sistem kaderisasi serta kultur ideologi yang kuat.

Kaitannya kaderisasi serta pengamalan ideologi yang kuat dengan konsistensi oposisi disini ialah kader memahami betul bahwa perannya ialah sebagai alat partai atau kendaraan partai untuk menyebarkan kebaikan bagi partai maupun masyarakat. Selain itu kader juga cenderung khusyuk dan tidak mudah digerakkan oleh kepentingan pragmatis semata, meskipun ditinggalkan oleh gerbong kekuasaan.

Apabila pemahaman ideologi dan kaderisasi sebuah partai sudah berhasil ditanamkan di setiap kader, maka dengan kesadaran penuh mereka akan dengan secara otomatis mengambil jalan oposisi apabila dirasa sudah tidak sejalan lagi dengan kepentingan ideologi partai, sehingga diperlukan pula adanya kemandirian dalam mengelola keuangan partai yang baik. Melihat bahwa basis partai ini adalah dakwah, atau bagi PKS berpolitik merupakan sebagian dari dakwah.

Jika sekalipun tidak mendapatkan kursi kekuasaan, mengalami kekalahan dalam pemilu, dalam hal ini yang terpenting ialah nilai dakwah yang difokuskan oleh PKS. Sehingga hal ini dapat menjelaskan mengapa PKS berusaha untuk konsisten dalam menjalankan fungsi oposisinya selama dua periode, hal itu dipengaruhi oleh kemandirian partai yang terbiasa bekerja dalam kekurangan secara ekonomi maupun secara politik, meskipun elektabilitasnya mencapai $7 \%$. (Noor, 2016: 14)

Dilihat dari kegiatan-kegiatan aksi kolektif Jamaah Tarbiyah, KAMMI, LDK, seperti aksi-aksi kegiatan sosial, pengumpulan dana, demonstrasi, tabligh akbar, dan istighotsah yang dilakukan oleh kader partai juga dapat dilihat sudah sangat lumrah. PKS terbiasa mengaktifkan kadernya bukan hanya per lima tahun sekali, akan tetapi setiap hari melalui aktivis-aktivis yang sering datang ke masyarakat sebagai bentuk kepedulian mereka terhadap masyarakat.

Dalam hal ini dapat disimpulkan bahwa PKS terbiasa untuk bergerak secara mandiri dengan segala keterbatasan yang mereka punya meskipun hanya sendirian, karena memang PKS merasa memiliki modal alat politik yang sangat kuat yaitu para partisipannya. Sehingga baik diajak ataupun tidak ke dalam jajaran kekuasaan di masa kepemimpinan Joko Widodo, hal tersebut bagi Firman Noor tidak akan menjadi masalah, bahkan lebih terkesan sama-sama tidak saling mengharapkan satu sama lain. Meskipun partaipartai yang berada dalam bagian koalisi kekuasaan, memang secara empiris mendapatkan akses yang lebih mudah.

Sedangkan PKS tidak dapat menikmati akses tersebut. Bukan berarti partai penguasa akan selalu berhasil dalam mendapatkan hati masyarakat, apabila terjadi kesalahan maka akan ada kemungkinan untuk mendapatkan hukuman sosial dari masyarakat yaitu kehilangan kepercayaan rakyat.

Akan tetapi perlu diwaspadai oleh PKS bahwa pengeluaran dana kampanye maupun biaya operasional sehari-hari organisasi gerakan sosial membutuhkan dana yang terus meningkat di tiap tahunnya. Mmengingat biaya operasional PKS sebagian besar didanai dari kegiatan penggalangan kader seperti amal, zakat, infak, dan shadaqah. Tidak hanya itu saja, bagi kader yang duduk di kursi parlemen, Anis Matta dalam Burhannuddin menyatakan bawa $50-60 \%$ pendapatannya wajib dialokasikan ke dana partai. (Muhtadi, 2012:153154).

Apabila partai hanya mengandalkan iuran anggota serta usaha- usaha lain yang legal dan tidak mengikat, tidak dapat banyak membantu partai untuk mendukung kebutuhan sehari-hari ataupun pengamalan agenda dan program kerja, termasuk pengkaderan.

Di sisi lain juga perlu dilihat, apabila partai mengalami kegagalan dalam mendanai kehidupan partai dan kemudian lebih banyak berpangku tangan kepada penguasa, hal tersebut akan menjadi sumber dari munculnya praktik yang menyimpang. Atau bisa saja sebaliknya yaitu apabila donatur mengincar kursi jabatan, maka akan ada kemungkinan pada akhirnya akan berubah haluan meski-pun partai tersebut sangat konservatif.

Sehingga kemudian partai akan menghadapi dua pilihan yaitu yang pertama ialah mati suri demi menjaga idealismenya, atau pilihan yang kedua yaitu menyerah pada kenyataan dan bergabung dengan pemerintah. (Noor, 2016:14).

Meskipun dalam sistem politik Indonesia oposisi ini belum mutlak keberadaannya, namun bagi Nurcholis Madjid partai politik yang bergerak sebagai oposisi tetap diperlukan sebagai penyeimbang kekuasaan (check and balance). Apabila tidak ada oposisi dalam demokrasi, maka yang akan terjadi adalah penyimpangan kekuasaan yang dapat mengancam kehidupan berdemokrasi. diharapkan oleh PKS sebagai salah satu upaya guna meningkatkan apresiasi publik terhadap partai oposisi, serta meningkatkan angka keterpilihannya serta dukungan di pemilu yang akan.

Dengan adanya PKS sebagai partai yang menyatakan oposisi di saat datang. Dampak yang didapatkan oleh minimnya partai yang menyatakan diri sebagai oposisi terhadap pemerintah, maka dengan begitu fungsi check and balance tetap dapat terjaga dan berjalan. Mengingat apabila komposisi kekuasaan gemuk tentunya akan mengaburkan pandangan rezim dalam membuat kebijakan yang fair. (Noor, 2016:15). 


\section{PENUTUP}

Meskipun oposisi kawan-kawan di periode 2019 seperti Gerindra, Golkar, PAN, PPP sudah tidak berada dalam satu gerbong lagi. Sikap tegas dalam menentukan sikap politiknya untuk tetap konsisten beroposisi. Sikap tersebut PKS sebagai oposisi di periode 2014- 2019 dan periode 2019-2024 ialah terjadinya peningkatan suara yang signifikan, PKS juga lebih leluasa dalam menyatakan pendapatnya dalam parlemen karena berada di luar gerbong pemerintahan. Tentu saja kedua hal tersebut menguntungkan bagi partai. Kemudian fungsi check and balance juga terjaga.

\section{DAFTAR PUSTAKA}

Admojo, Tuswoyo. 2016. "Peran Partai Oposisi di Parlemen Pasca Pemilu Presiden 2014", Jurnal Politik, Vol.1 No. 2, Desember.

Agustino, Leo. 2014. "Pemilihan Umum di Indonesia Tahun 2014", Prisma Majalah Pemikiran Sosial Ekonomi Demokrasi di Bawah Cengkraman Oligarki, Vol.33 No.1, Januari.

Akmar, Zaiyatul. 2019. "Konflik Internal Partai Keadilan Sejahtera Tahun 2016: Studi Kasus Konflik Fahri Hamzah dengan Pimpinan DPP PKS", Jurnal Ilmu Politik, Vol.10 No.1, April.

Erdianto, Kristian. 2019. "Mungkinkah Hanya PKS Yang Bertahan Jadi Oposisi?", https://nasional.kompas.com, 29 Juni.

Kompas.com. 2019. "Fahri Hamzah Prediksi PKS Tak Mampu Lolos Ke DPR di Pemilu 2019"Kompas.com, 03 Maret.

Madjid, Nurcholish. 1998. Dialog Keterbukaan. Jakarta: Paramadina, 1998.

Muhtadi, Burhanuddin. 2012. Dilema PKS: Suara dan Syariah. Jakarta: Kepustakaan Populer Gramedia.

Nainggolan, Bestian. 2016. Partai Politik Di Indonesia 1999-2019: Konsentrasi dan Dekonsentrasi Kuasa. Jakarta: Kompas Media Nusantara.

Noor, Firman. 2016. “Oposisi Dalam Kehidupan Demokrasi: Arti Penting Keberadaan Oposisi Sebagai", Masyarakat Indonesia, Vol. 42 No.1, Juni.

Prasetio, Ade. 2018. "Model Oposisi Partai Politik Di Indonesia: Studi Respons Gerindra dan PKS Terhadap Pemerintah Joko Widodo-Jusuf Kalla Pada Tahun 2014-2017", Skripsi S1, UIN Syarif Hidayatullah.

Suryani. 2018. Disalignment of Political Parties in Indonesia: Study on the Declining Electability of Prosperous Justice Party (PKS) in General Election 2014. Atlantis Press: Third International Conference on Social and Political Sciences (ICSPS 2017). 